\title{
ESTETIKA GERAK TARI DADI RONGGENG BANYUMASAN
}

\author{
Mutiara Putri Titisantoso, Indriyanto, Usrek Tani Utina \\ FBS, Universitas Negeri Semarang \\ Email: Mutiaraputri125509@gmail.com
}

\begin{abstract}
Abstrak
Tari Dadi Ronggeng merupakan sebuah karya tari yang berpijak pada unsur gerak banyumasan. Keindahan Tari Dadi Ronggeng dapat dilihat melalui geraknya. Keindahan gerak tersebut dapat dilihat melalui aspek dasarnya yaitu ruang, waktu, dan tenaga. Tujuan dari penelitian ini adalah untuk mengetahui estetika gerak tari yang terdapat pada Karya Tari Dadi Ronggeng Banyumasan. Metode penelitian yang digunakan adalah metode penelitian kualitatif dengan menggunakan pendekatan deskritif kualitatif, pendekatan etik dan emik dan pendekatan estetis koreografis, dengan menggunakan teknik pengumpulan data wawancara, observasi, dan dokumentasi. Teknik analisis data yang digunakan adalah Teori Adshead, dkk. Berdasarkan hasil penelitian yang telah dilakukan, gerak sebagai media pokok Tari Dadi Ronggeng dapat mencerminkan nilai keindahan. Keindahan gerak terbentuk melalui jalinan pola penggunaan ruang, waktu, dan tenaga yang menghasilkan keindahan yang khas. Penggunaan volume gerak yang cenderung lebar dengan tempo yang bervariasi namun tetap menggunakan intensitas tenaga yang besar memberikan kesan energik, seksi, dan ceria.
\end{abstract}

Kata Kunci: dadi ronggeng, estetika, gerak tari.

\section{AESTHETIC MOVEMENT OF DADI RONGGENG BANYUMASAN DANCE}

\begin{abstract}
Dadi Ronggeng is a dance with the basic of Banyumasan. The beauty of a Dadi Ronggeng dance can be seen through its movement. The beauty of the movement can be seen through its basic aspects, namely space, time, and energy. The purpose of this study is to determine the aesthetics of dance movements found in the Dadi Ronggeng dance. The research method is a qualitative research with a qualititative descriptive approach, ethical and emic approaches, and an aesthetic choreograpic approach. The data collection techniques were interviews, observation, and documentation. The Adshead Theory et al was applied as data analysis technique. Based on the results of research that the beauty of the movement in the Dadi Ronggeng Dance is formed by relating the use space, time, and energy in the dance. The combination of twisting movements, the use of movement volumes that tend to be wide with varying tempo but still using a large intensity of energy gives an energetic, sexy and cheerful.
\end{abstract}

Keywords: dadi ronggeng, aesthetic and dance movement.

\section{PENDAHULUAN}

Gerak dan tari merupakan satu kesatuan, karena dengan adanya gerak maka munculah sesuatu yang disebut dengan tari. Tari adalah ungkapan jiwa manusia lewat gerak badan yang dapat diiringi dengan bunyi-bunyian dan memiliki keindahan (Utina 2009: 4). Gerak dalam tari adalah gerak yang sudah ditata sedemikian rupa yang telah di sesuaikan dengan tema, konsep dan isi tarian, sehingga 
menjadi indah. Salah satu tarian yang memiliki nilai keindahan adalah Tari Dadi Ronggeng.

Menurut Jazuli (1994: 114) pada tari, kita dapat memproyeksikan keindahan melalui gerakan-gerakan yang bersamaan dengan rasa kepuasan dalam diri kita (pengalaman estetis), dalam keadaan seperti itu kita dapat berkata bahwa "gerakan tari itu sangat indah". Berdasarkan perkataan tersebut maka tari lewat gerakan-gerakannya telah bertemu dengan kebutuhan (tuntutan) estetis kita.

Djelantik (1999: 9) menjelaskan bahwa ilmu estetika adalah suatu ilmu yang mempelajari segala sesuatu yang berakitan dengan keindahan, mempelajari semua aspek dari apa yang kita sebut keindahan. Djelantik (1999: 4) juga menjelaskan bahwa pada umumnya apa yang kita sebut indah di dalam jiwa kita dapat menimbulkan rasa senang, rasa puas, rasa aman, nyaman, dan bahagia dan bila perasaan itu sangat kuat, kita merasa terpaku, terharu, terpesona serta menimbulkan keinginan untuk mengalami kembali perasaan itu, walaupun sudah dinikmati berkali-kali.

Astini dan Utina (2007: 175) menjelaskan bahwa estetika dalam seni adalah sesuatu yang hanya bisa dinikmati dengan rasa. Rasa keindahan pada tari dapat terwujud melalui keutuhan penggarapanyang dapatmenimbulkan rasa ketertarikan pada semua penikmatnya.

Gerak adalah media pokok tari. Keindahan sebuah tari dapat dilihat melalui geraknya. Keindahan gerak tersebut dapat dilihat melalui aspek dasarnya yaitu ruang, waktu, dan tenaga. Gerak sebagai media pokok Tari Dadi Ronggeng, dapat mencerminkan nilai keindahan pada tarian tersebut. Keindahan gerak dari Tari Dadi Ronggeng terbentuk dari jalinan pola penggunaan ruang, waktu, dan tenaga. Pola penggunaan ruang, waktu, dan tenaga menghasilkan keindahan yang khas pada Tari Dadi Ronggeng dan keindahan yang khas pula terwujud melalui perpaduan gerak dengan properti cowongan yang digunakan.

Tari Dadi Ronggeng merupakan tari kreasi baru yang masih berpijak pada aturan-aturan baku baik pola-pola gerak maupun musik iringannya. Tari Dadi Ronggeng merupakan karya dari Sanggar Seni Sekar Shanty yang diciptakan pada tahun 2003, yang disajikan dalam acara Borobudur International Festival. Tari Dadi Ronggeng kemudian mendapat penghargaan sebagai Penyaji Terbaik II Festival Tari Rakyat Tingkat Jateng.

PadaawalpenciptaanyaTariDadiRonggeng (versi pertama) ditarikan oleh penari putra dan penari putri dengan satu sosok perempuan yang berperan menjadi dukun yang bertugas menobatkan penari tersebut untuk menjadi seorang ronggeng, tugas penari putra sebagai lelaki yang menggoda penari putri ketika dia sudah dinobatkan sebagai ronggeng. Pada Tari Dadi Ronggeng (versi pertama) di dalamnya juga terdapat dialog antara penari putri dan penari putra sebelum mereka akhirnya menari bersama, walaupun dengan alur cerita yang sama yaitu mengisahkan penobatan seorang ronggeng, akan tetapi gerak yang tersaji berbeda, durasi yang terdapat pada Tari Dadi Ronggeng (versi pertama) juga lebih lama.

TariDadiRonggengyangmenarik perhatian peneliti adalah Tari Dadi Ronggeng garapan baru (versi kedua) yang tentunya bermula dari Tari Dadi Ronggeng yang pertama kali tercipta dan tentunya juga Tari Dadi Ronggeng (versi kedua) memiliki durasi pementasan yang lebih singkat, sehingga karya tari versi kedua lebih sering dipentaskan, bahkan pada awalnya karya tari versi kedua ini dipersingkat durasinya guna keperluan dokumentasi dari Stasiun TV Indosiar yang mendokumentasikan kesenian yang hampir punah yang kemudian dipadatkan menjadi sebuah karya tari. Karya Tari Dadi Ronggeng (versi kedua) lebih menarik untuk dikaji, karena menggunakan properti cowongan. Penggunaan properti cowongan mampu menambah keindahan gerak yang terdapat pada Tari Dadi Ronggeng.

Tari Dadi Ronggeng merupakan karya tari yang menggambarkan seseorang yang belum jadi apa-apa menjadi apa-apa, dari seseorang biasa (sebelum jadi ronggeng) sampai menjadi sosok seorang ronggeng. Ritual awal digambarkan dengan menggunakan properti cowongan (media masuknya bidadari), ronggeng di gambarkan laksanan bidadari, 
sebab ronggeng nantinya akan menjadi bintang panggung, semua orang akan mendambakan sosok seorang ronggeng, akan menanti-nanti, dan menunggu kedatangan seorang ronggeng. Sosok ronggeng akan menjadi dambaan dan pujaan bagi masyarakat, hal tersebut terjadi karena indang ronggeng yang masuk kedalam tubuh penari.

Rias dan kostum penari pada Tari Dadi Ronggeng menggambarkan cowongan yang merupakan simbol bidadari.Rias penari dan kostum yang digunakan akan menyerupai rias dan kostum yang ada pada cowongan. Gerak tarian dari Tari Dadi Ronggeng menggambarkan sosok ronggeng. Konsep bidadari adalah perwujudan dari konsep indang yang masuk ke dalam diri penari ronggeng.

Proses penilaian keindahan terjadi karena adanya perbedaan penilaian sudut pandang dari penikmat karya seni, hal tersebut menjadikan adanya perbedaaan penentuan letak keindahan apakah ada di objek, di subjek atau bahkan terletak pada subjek-objek.

Keindahan subjektif menyatakan bahwa ciri-ciri keindahan pada suatu objek sesungguhnya tidak ada, keindahan hanyalah tanggapan perasaan dalam diri subjek yang mengamati objek tersebut, keindahan sematamata tergantung pada pencerapan pengamat, dengan demikian bersifat relatif. Singkat kata, keindahan terdapat pada pemahaman spektator (Junaedi 2017: 197).

Keindahan objektif melihat keindahan sebagai sifat yang melekat pada objek, terlepas dari pengamatan, spektator hanya menemukan atau menyingkap sifat indah yang sudah ada pada suatu benda dan sama sekali tidak mampu mempengaruhi atau mengubahnya. Dengan kata lain, menurut keindahan objektif, keindahan terletak pada objek estetis (Junaedi 2017: 197).

Keindahan subjektif-objektif melihat keindahan muncul karena subjek mengalami pengalaman keindahan yang dibangkitkan oleh properti keindahan pada objek (Junaedi 2017: 198).

Dari latar belakang tersebut maka peneliti merumuskan satu rumusan masalah yaitu bagaimana estetika gerak tari yang adapadaTariDadi Ronggeng?.

\section{METODE}

Metode penelitian yang digunakan adalah metode penelitian kualitatif, dengan menggunakan pendekatan deskriptif kualitatif, pendekatan etik dan emik, dan pendekatan deskriptif kualitatif. Pendekatan deskriptif kualitatif digunakan dalam penelitian untuk mengkaji mengenai keindahan koreografi gerak Tari Dadi Ronggeng yang berkaitan dengan ruang, waktu, dan tenaga.

Lokasi penelitian berada di Sanggar Seni Sekar Shanty. Sanggar Seni Sekar Shanty merupakan sebuah sanggar seni yang berlokasi di Jalan Krajan nomor 1, RT 02 RW 01, Desa Karangjati, Kecamatan Susukan, Kabupaten Banjarnegara. Sanggar Seni Sekar Shanty didirikan oleh Bapak Yusmanto dan Ibu Susanty pada tahun 2004.

Teknik pengumpulan data menggunakan observasi partisipan, wawancara dan dokumentasi, pada penelitian yang telah dilakukan mengenai Estetika Gerak Tari Dadi Ronggeng Banyumasan.

Uji keabsahan data dalam penelitian Estetika Gerak Tari Dadi Ronggeng Banyumasan menggunakan teknik triangulasi. Peneliti dalam melakukan uji keabsahan data dengan menggunakan metode triangulasi. Triangulasi yaitu menggunakan berbagai teknik pengumpulan data secara gabungan/simultan (Sugiyono 2015:15).

Teknik analisis data yang digunakan menggunakan Teori Adshead Indriyanto (2011) dalam Jurnal Harmonia yang berjudul Pengaruh Tari Jawa pada Tari Baladewa Banyumasan menggunakan analisis tari model Adshead (1988) yang menggunakan langkah-langkah analisis data tari dengan mendeskripsikan, menginterpretasikan dan mengevaluasi.

\section{HASIL DAN PEMBAHASAN \\ Estetika Gerak Tari Dadi Ronggeng Banyumasan}

Estetika gerak Tari Dadi Ronggeng muncul karena menggunakan semua elemen- 
elemen tubuh yaitu kepala, badan, tangan, dan kaki. Keserasian dan keterpaduan gerakgerak yang seirama menghasilkan estetika gerak yang indah yang dipadukan dengan iringan, properti rias dan busana yang semakin menambah suasana yang tercipta. Kesemuanya menghasilkan kesan gerak yang lembut, namun tetap bertenaga dan memiliki daya tarik dan pesona yang tinggi pada penarinya, sehingga terlihat seksi dan ceria.

\section{Deskripsi Pertunjukan Tari Dadi Ronggeng Banyumasan}

26 September 2018, suasana hari itu sangat ramai. Banyak warga yang berbondongbondong datang dengan sangat antusias, untuk mengikuti dan menyaksikan serangkaian kegiatan dalam acara Festival Ujungan 2018, yang berlokasi di Lapangan Desa Kemranggon, Kecamatan Banyumas. Tari Dadi Ronggeng menjadi salah satu sajian yang dipentaskan pada Festival Ujungan 2018. Terik mentari yang masih cukup menyengat di sore hari, tidak mengurangi minat warga untuk berdesakan, berebut tempat terdepan ketika para penari Dadi Ronggeng mulai menaiki panggung.

Area pentas yang sudah dihias sedemikian rupa dengan menggunakan jerami, menambah kesan kultur kerakyatan dan kesuburan pada acara tersebut. Musik mulai diputar, keriuhan warga semakin terasa. Penari telah siap memposisikan dirinya, dengan susunan berbanjar disebelah kanan panggung dari sudut pandang penonton. Penari mulai berjalan keluar, mengikuti iringan musik dengan tempo yang sedang. Hanya beberapa langkah setelahnya, penari mulai menari dengan gerakan bebas namun tetap berpijak pada pola kendangan yang ada.

Masuk pada suasana yang semakin sakral. Penari melakukan gerak sembahan dengan menyatukan kedua telapak tangannya dengan gerakan yang pelan. Hingga kedua tangan lurus, diatas kepala, kemudian membawanya turun dan mengambil properti cowongan. Setelahnya, mantra cowongan mulai dilantunkan dalam iringan tersebut. Penari dan penonton ikut hanyut dalam suasana. Setelahnya para penari melakukan gerakan intrance yang menambah kesan sakral pada bagian awal.

Tak kalah menarik adalah ketika masuk pada bagian inti, penari mulai menari dengan begitu lincah dan energik, menguasai setiap area panggung. Laksana tari pergaulan pada umumnya. Tarian banyumasan yang dikenal dengan gerakan yang patah-patah, sesekali ditonjolkan oleh penari. Namun tak dapat dipungkiri, gerakan yang lembut dengan gerakan tubuh yang meliuk-liuk tetap menjadi ciri khas tersendiri dari Tari Dadi Ronggeng. Suasana sore menjadi lebih ramai. Nampaknya senja tak ingin cepat berlalu. Warga masih tetap diposisinya, tetap menyaksikan setiap detail gerakan dari para penari.

Pada bagian akhir tarian, Tari Dadi Ronggeng tetap memberikan gerakan yang menarik. Gerakan yang seksi dengan iringan gending renggong garut menambah hanyut penonton dalam suasana. Tak terasa tarian pun mulai berakhir. Penari mulai beranjak, gerak ditutup dengan para penari melakukan gerak sembahan yang dilakukan seperti awal, untuk kemudian mengambil cowongan dan meninggalkan area pentas.

\section{Pola Gerak Tari Dadi Ronggeng Banyumasan}

Pola gerak Tari Dadi Ronggeng terbagi menjadi 3 bagian yaitu awal-inti-akhir. Pola gerak bagian awal meliputi lampah maju, sembahan, cowongan, intrance dan peralihan gerak dari lampah maju menuju inti. Pola gerak bagian inti meliputi panggelan I, lampah lambean tawing sampur, singgetan I (singgetan alon), entrakan, singgetan I (singgetan alon), ukel limbukan, singgetan I (singgetan alon separo), lampah lambean, lampah seblak sampur, panggelan II, entrakan II, singgetan II, timbangan lambean, singgetan II, seblakan gagah, keweran dawa, aburan I, panggelan III, kiprahan, panggelan III, kayang, singgetan III, gejolan, molak-malik, geol, keweran dan sindhetan IV dan lampah lambean. Pola gerak bagian akhir meliputi geol renggong garut, aburan II, panggelan II, daengan, keweran dan singgetan $V$, geolan, panggelan $I V$, awe-awe, 
keweran dan singgetan $V$, glombang banjir sor, keweran dan singgetan $V$, seblak sampur, panggelan III, sembahan dan lampah mundur.

\section{Deskripsi Ragam Gerak Tari Dadi Ronggeng Banyumasan}

Pada Tari Dadi Ronggeng terdapat banyak ragam gerak dan beberapa gerak penghubung yang saling memiliki keterkaitan, sehingga Tari Dadi Ronggeng memiliki keindahan gerak yang bagus dan mampu menarik perhatian para penikmat seni. Berikut ini adalah beberapadeskripsi ragam gerak Tari Dadi Ronggeng. Sebagai catatan jika deskripsi verbal yang peneliti buat merupakan penjelasan secara umum. Hal yang perlu diketahui adalah jika deskripsi verbal ini memiliki beberapa kekurangan, salah satu kekurangan dari deskripsi verbal adalah akan sulit dipahami oleh orang lain.

Gerak sembahan (2x8 hitungan) dilakukan dengan posisi badan berdiri tegak, kedua kaki sejajar, kedua tangan perlahan dari arah bawah digerakan ke samping perlahan digerakkan ke atas. Kedua telapak tangan disatukan dengan jari-jari tangan rapat, gerakan kepala mengikuti gerakan tangan perlahan menghadap atas. Kedua kaki rapat merendah secara perlahan, turun ke posisi duduk simpuh, sambil kedua tangan mengambil cowongan.

Gerak panggelan I (4 hitungan) dilakukan dengan posisi melangkah kaki kanan (nyilang) dengan pelan ke depan, sambil kebyok kedua sampur. Maju kaki kiri diletakan sejajar dengan kaki kanan, sambil kebyak kedua sampur. Bawa kedua sampur ke depan pusar sambil posisi tangan ngiting. Seblak kedua sampur ke samping tanpa melepas sampur.

Gerak aburan I ( $5 \times 8+4$ hitungan) dilakukan dengan gerakan kaki tranjal dengan tempo yang cepat. Ketika melangkah kaki kanan, tangan kiri pegang sampur sambil nyekiting, tangan kanan bergerak mengikuti langkah kaki, kaki kanan maju berati posisi tangan kanan lurus ke bawah (jari tangan ngiting menghadap bawah), tangan kiri ke atas setinggi dahi pergelangan tangan nyeklek hadap bawah. Maju kaki kiri, tangan kanan di atas setinggi dahi, tangan kiri lurus ke bawah, tolehan ke arah tangan yang di atas.

Gerakawe-awe (2x8+4hitungan) dilakukan dengan posisi balik badan ha dap kiri (sambil badan di liukan ke kiri mengikuti gerakan kaki). Kaki kanan dilangkahkan, kaki kanan depan, dan kaki kiri berjinjit di belakang. Diikuti gerakan kedua tangan di dorong ke samping kanan, dengan posisi telapak tangan menghadap bawah (sikap jari ngrekoto), setelahnya balik kedua telapak tangan menghadap atas dengan diberikan tekanan pada bagian pergelangan, gerakan tangan selaras dengan gerakan kaki. Kedua pergelangan tangan digerakan ke atas secara bersamaan (dengan tekanan). Posisi kaki kiri jinjit kemudian mendhak (setiap kaki mendhak, setiap itu pulang pergelangan tangan di gerakan keatas dengan tekanan). Gerak kepala dipatahkan mengikuti kaki dan tangan. Melangkah kaki kiri. Balik badan hadap kanan. Kaki kanan jinjit, bersamaan dengan tangan kiri lurus ke samping kiri setinggi pinggul (sikap jari ngrekoto), tangan kanan trap cethik. Bahu gerakan kebelakang dua kali dengan tekanan. Posisi kaki kanan jinjit, kaki kiri menapak. Tolehan selalu kearah depan. Balik badan hadap kiri (sambil badan di liukan ke kiri mengikuti gerakan kaki). Kaki kanan dilangkahkan, kaki kanan depan, dan kaki kiri berjinjit di belakang. Diikuti gerakan kedua tangan di dorong ke samping kanan, dengan posisi telapak tangan menghadap bawah (sikap jari ngrekoto), setelahnya balik kedua telapak tangan menghadap atas dengan diberikan tekanan pada bagian pergelangan, gerakan tangan selaras dengan gerakan kaki. Kedua pergelangan tangan digerakan ke atas secara bersamaan (dengan tekanan). Posisi kaki kiri jinjit kemudian mendhak (setiap kaki mendhak, setiap itu pulang pergelangan tangan di gerakan keatas dengan tekanan). Gerak kepala dipatahkan mengikuti kaki dan tangan. Kaki kiri melangkah (putar ke kiri) hadap belakang. Posisikan kedua kaki sejajar dibuka selebar bahu. Pinggul digerakan kanan-kiri-kanan sambil kedua tangan trap cethik pegang sampur, dicutatkan bergantian bersamaan dengan gerak pinggul. Selanjutnya 
balik kanan menghadap depan. Badan hadap depan, kedua tangan ditekuk ke samping kanan, posisi kedua telapak tangan hadap atas. Kedua pergelangan tangan digerakan ke atas secara bersamaan (dengan tekanan). Posisi kaki kiri jinjit kemudian mendhak (setiap kaki mendhak, setiap itu pulang pergelangan tangan di gerakan keatas dengan tekanan). Gerak kepala dipatahkan mengikuti kaki dan tangan.

\section{Unsur Gerak Tari Dadi Ronggeng Banyumasan}

Ragam gerak Tari Dadi Ronggeng terdiri dari unsur gerak. Unsur gerak merupakan bagian terkecil yang belum memiliki makna (Noviyanti, 2017: 100). Unsur gerak terdiri dari unsur gerak kepala, tangan, kaki, dan badan.

Unsur gerak kepala terdiri dari tolehan, tolehan kanan, tolehan kiri, lenggut, patahan, patahan kanan, dan patahan kiri. Unsur gerak tangan terdiri dari sikap menthang, menthang kanan, menthang kiri, menthang keduanya, trap cethik, ngiting, dan ngrekoto. Unsur gerak tangan juga terdiri dari gerak sembahan, semblak sampur, cutatan sampur, lambean sampur, ukel, ukel separo, keweran, kebyok sampur, dan kebyak sampur. Unsur gerak kaki terdiri dari sikap mendhak dan jinjit. Unsur gerak kaki juga terdiri dari gerak tranjal, debeg, gejug, seret, lampah, dan loncat. Unsur gerak badan terdiri dari sikap ndegeg. Unsur gerak badan juga terdiri dari gerak entrakan, obah bahu dan kayang.

\section{Nilai Keindahan Gerak Tari Dadi Ronggeng Banyumasan}

Gerak pada sebuah pementasan karya tari dapat menyampaikan pesan kepada penonton mengenai pesan yang ingin disampaikan oleh pencipta karya tari. Gerak tari pada Tari Dadi Ronggeng sebenarnya tidak memiliki gerakan yang baku (gerakan yang tetap/paten/tidak dapat diubah), namun tetap berpatokan pada pola kendangannya.

Pola-pola gerak Tari Dadi Ronggeng masih menggunakan pijakan gerak gaya banyumasan yang masih terlihat asli kerakyatannya, sehingga banyak gerakan meliuk-liuk tubuh pada tarian tersebut. Gerakan yang meliuk itulah yang menjadi ciri khas dari gerak yang ada pada Tari Dadi Ronggeng.

Selain gerakan yang menjadi ciri khasnya, Tari Dadi Ronggeng (versi kedua) juga menggunakan properti cowongan, yang tentunya sangat membedakan dengan tariantarian banyumasan pada umumnya. Selain hal tersebut ciri khas lain juga terletak pada rias dan busana si penari yang didandani semirip mungkin dengan cowongan dan juga rias wajahnya menggunakan gedong (pidih hitam yang biasa di pasang di pengantin adat jawa).

Pada Tari Dadi Ronggeng Banyumasan untuk menilai kualitas kepenarian yang tentunya mampu untuk menilai keindahan gerak tari yang dilakukan oleh penari dapat dilihat melalui wiraga yaitu bagaimana sang penari membawakan tari Dadi Ronggeng sehingga memunculkan kesan tarian yang energik, seksi, dan ceria. Wirama yaitu bagaimana para penari Tari Dadi Ronggeng memiliki kepekaan terhadap irama sehingga memberikan kesan tarian yang seimbang dan memiliki keselarasan dengan irama musik yang dimainkan. Wirasa yaitu bagaimana para penari Tari Dadi Ronggeng membawakan tarian dengan penuh penghayatan pada tiap-tiap pola gerak sehingga memberikan kesan mistis pada bagian awal tarian, memberikan kesan ceria pada bagian inti dan memberikan kesan seksi pada bagian akhir Tari Dadi Ronggeng.

Gerak pada Tari Dadi Ronggeng menggunakan gerak yang serupa dengan gerak-gerak lengger, seperti gerak keweran untuk gerak penghubungnya, hal tersebut dikarenakan Ibu Susanty sebagai koreografer sangat menyukai gerak-gerak lengger, sehingga karya yang tercipta memang menirukan gerak lengger yang asli, hanya lebih dikembangkan lagi.

Penggunaan ruang gerak pada Tari Dadi Ronggeng menggunakan gerak meliuk-liuk dan cenderung bervolume lebar. Penggunaan tempo bergantung dengan suasana yang ingin diciptakan. Pada bagian awal memiliki suasana mistis dengan menggunakan gending gunung sari yangdi dalamnya terdapat mantra 
cowongan. Pada bagian inti memiliki suasana tari pergaulan (ceria) dengan menggunakan gending ketawang tlutur, lancaran tlutur kemudian renggong lor. Bagian akhir memiliki suasana yang seksi dengan menggunakan gending renggong garut. Walaupun gerakan pada Tari Dadi Ronggeng gerakannya meliukliuk akan tetapi gerakannya tetap menggunakan intensitas gerak yang besar, barulah nantinya aksen/tekanan yang digunakan menggunakan aksen/tekanan yang kecil.

Jenis gerak yang digunakan adalah gerak maknawi. Gerak maknawi digunakan hanya pada awal tarian pada saat penari memegang cowongan (melakukan ritual). Bagian inti dan bagian akhir tidak menggunakan gerak maknawi, melainkan menggunakan gerakgerak murni.

Berikut beberapa keindahan gerak dari ragam gerak Tari Dadi Ronggeng Banyumasan.

Gerak sembahan pada elemen badan bergerak dengan tegap, sehingga memberikan kesan yang kokoh. Begitu juga dengan elemen kaki yang tidak banyak bergerak memberikan kesan yang tenang. Elemen tangan memberikan kesan sakral karena digerakan dengan pelan dan mengisyaratkan gerak menyembah. Elemen kepala pada gerak sembahan memberikan kesan sakral karena arah pandang mengikuti pergerakan tangan yang bergerak dari atas ke bawah.

Nilai keindahan gerak sembahan dapat dilihat dari aspek ruang, waktu, dan tenaga. Aspek ruang dapat dilihat dari garis, volume, arah, dan fokus pandangan. Penggunaan garis pada gerak sembahan lebih banyak menggunakan garis lurus sehingga memberikan kesan agung dan sakral, ditambah dengan penggunaan volume gerak tangan yang lebar memberikan kesan kokoh. Perpindahan arah gerak penari atau penggunaan arah yang monoton pada gerak sembahan memberikan kesan sederhana dan tenang. Penggunaan fokus pandangan yang menyelaraskan gerak tangan memberikan kesan keseimbangan dan tenang.

Nilai keindahan gerak sembahan dilihat dari aspek waktu dapat dilihat dari aspek tempo, ritme, durasi, dan irama. Penggunaan tempo pada ragam gerak sembahan sangat sederhana dan lebih banyak menggunakan tempo lambat sehingga memberikan kesan tenang. Penggunaan ritme lebih teratur sehingga memberikan kesan sederhana, dengan penggunaan durasi gerak gerak sembahan yang tidak lama memberikan kesan yang tidak membosankan ditambah dengan irama yang senada dengan mantra yang dibacakan yang berbunyi sulasih sulanjana kukus menyan ngundang dewa ana dewa ndaning sukma widadari tumuruna yang memberikan kesan sakral.

Nilai keindahan geraksembahan dilihat dari aspek tenaga dapat dilihat dari intensitas, aksen/ tekanan, dan kualitas. Pengunaan intensitas pada gerak sembahan menggunakan intensitas tenaga yang sedang, namun tanpa adanya penggunaan aksen/tekanan yang menonjol sehingga memberikan kesan tenang, kuat dan sakral. Kesemuanya menghasilkan kualitas gerak yang indah dengan harmonisasi gerak yang bercampur padu dengan mantra (sulasih sulanjana kukus menyan ngundang dewa ana dewa ndaning sukma widadari tumuruna) yang dibacakan memberikan kesan keindahan gerak yang sakral, agung dan tenang.

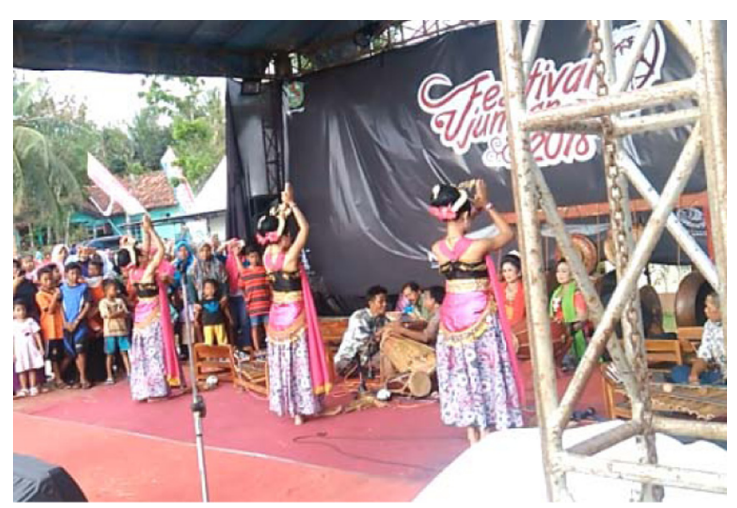

Gambar 1. Salah Satu Sikap dari Ragam Gerak Sembahan (Foto: Mutiara, 26 September 2018)

Nilai keindahan gerak sembahan dilakukan dengan sakral. Pada saat gerak sembahan, kaki diam ditempat sehingga memberikan kesan yang tenang. Keselarasan gerak tangan dengan 
pandangan dan dengan tempo yang pelan memberikan kesan agung dan sakral. Posisi badan berdiri tegap (ndegeg) memberikan kesan kokoh.

Gerak panggelan I pada elemen badan bergerak meliuk, sehingga memberikan kesan lembut. Pada elemen kepala bergerak menoleh kanan dan kiri dengan pelan memberikan kesan yang lembut dan manis. Elemen gerak kaki bergerak melangkah dengan pelan memberikan kesan lembut dan sederhana. Begitu juga dengan elemen gerak tangan yang bergerak memainkan sampur dengan pelan memberikan kesan yang lembut namun cukup variatif.

Nilai keindahan gerak panggelan Idapat dilihat dari aspek ruang, waktu, dan tenaga. Aspek ruang dapat dilihat dari garis, volume, arah, dan fokus pandangan. Penggunaan garis lebih banyak menggunakan garis lengkung sehingga memberikan kesan gerak yang lembut, dengan volume gerak yang sempit memberikan kesan kewanitaan dan lembut. Penggunan arah gerak penari yang sederhana memberikan kesan minimalis. Fokus pandangan penari lebih banyak menoleh kanan-kiri mengikuti langkah kaki dan tangan memberikan kesan teratur dan lembut.

Nilai keindahan gerak panggelan I dilihat dari aspek waktu dapat dilihat dari aspek tempo, ritme, durasi, dan irama. Penggunaan tempo yang pelan memberikan kesan sederhana. Begitu juga dengan penggunaan ritme dan irama yang tidak begitu variatif memberikan kesan kesederhanaan, selain itu penggunaan durasi sangat singkat yaitu hanya 4 hitungan, sehingga tidak memberikan kesan yang membosankan.

Nilai keindahan gerak panggelan I dilihat dari aspek tenaga dapat dilihat dari intensitas, aksen/tekanan, dan kualitas. Penggunaan intensitas gerak, menggunakan intensitas yang rendah memberikan kesan gerakan yang lembut, sedangkan penggunaan aksen/tekanan yang hampir tidak ada memberikan kesan mengalir. Perpaduan penggunaan intensitas dan aksen/ tekanan memberikan kesan harmonisasi dan keindahan gerak yang sederhana dan lembut.
Nilai keindahan gerak panggelan $I$ dilakukan dengan lembut. Pada saat bergerak kaki dan tangan digerakan dengan lembut dengan fokus pandangan yang juga ikut digerakan seirama dengan tangan dan kaki memberikan kesan lembut dan terlihat harmonisasi yang seimbang. Gerakan badan yang banyak menggunakan garis lengkung dengan gerakan yang sedikit diayunkan memberikan kesan manis dan lembut.

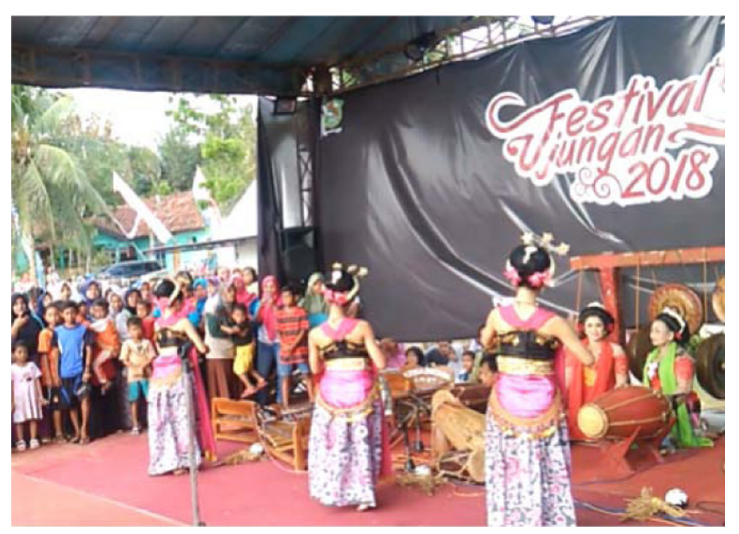

Gambar 2. Salah Satu Sikap dari Ragam Gerak Panggelan I

(Foto: Mutiara, 26 September 2018)

Gerak aburan I pada elemen gerak kaki berjalan dengan kedua kaki menjinjit memberikan kesan lincah dan dinamis. Gerakan pada elemen kepala menoleh pada gerakan tangan yang berada di atas memberikan kesan manis. Gerakan elemen tangan yang bergerak naik turun memberikan kesan lincah.

Nilai keindahan gerak aburan I dapat dilihat dari aspek ruang, waktu dan tenaga. Aspek ruang dapat dilihat dari garis, volume, arah, dan fokus pandangan. Pada gerak aburan $I$ lebih banyak menggunakan garis lengkung memberikan kesan lembut. Penggunaan volume gerak yang tidak terlalu lebar memberikan kesan yang feminin. Arah perpindahan gerak penari bisa aktif menguasai arena pentas memberikan kesan ramai dan lincah. Fokus pandangan yang mengikuti gerakan tangan yang berada di posisi atas memberikan kesan manis.

Nilai keindahan gerak aburan I dilihat dari aspek waktu dapat dilihat dari aspek tempo, ritme, durasi, dan irama. Penggunaan 
durasi yang lama yaitu $5 \times 8+4$ hitungan namun dilakukan dengan tempo dan ritme yang cepat memberikan kesan lincah dan energik. Penggunaan irama dengan pengelolaan cepat lambatnya gerak dilakukan dengan baik, sehingga memberikan kesan menarik.

Nilai keindahan gerak aburan I dilihat dari aspek tenaga dapat dilihat dari intensitas, aksen/tekanan, dan kualitas. Penggunaan intensitas yang sedang memberikan kesan yang manis dipadukan dengan penggunaan aksen/tekanan pada bagian kepala memberikan kesan menarik dan lincah. Perpaduan penggunaan intensitas dan aksen/tekanan yang sedang, dilihat dari pergerakan kepala dan kaki menghasilkan kualitas gerak yang bagus, sehingga memberikan kesan yang seimbang dan tidak berlebihan.

Nilai keindahan gerak aburan I dilakukan dengan lincah dan energik. Kelincahan dan keenergikan gerak terlihat dari langkah kaki (tranjal) yang memberikan kesan ramai dan dinamis. Gerakan tubuh pada gerak aburan I membentuk garis lengkung karena badan ikut meliuk-liuk mengikuti langkah kaki sehingga memberikan kesan lembut namun terkesan lincah.

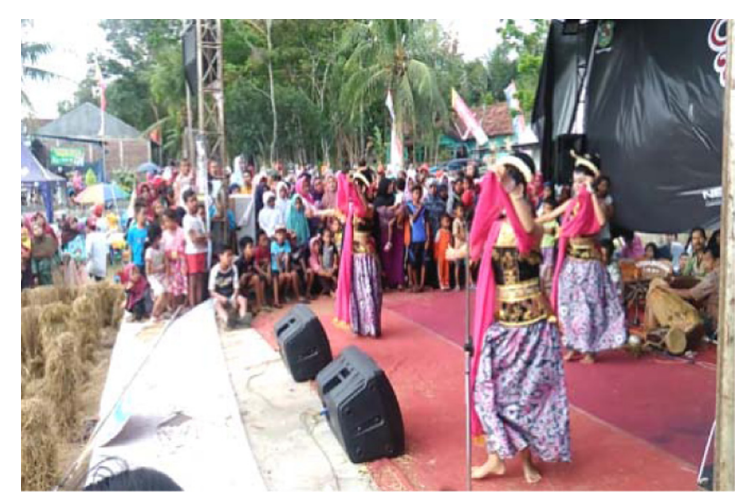

Gambar 3. Salah Satu Sikap dari Ragam Gerak Aburan I

(Foto: Mutiara, 26 September 2018)

Gerak awe-awe pada elemen badan dan elemen tangan bergerak dengan meliuk-liuk, sehingga memberikan kesan luwes. Gerakan elemen kaki yang dipadukan dengan gerak kaki menjinjit memberikan kesan lincah. Posisi elemen kepala yang menoleh kearah depan memberikan kesan anggun dan manis.

Nilai keindahan gerak awe-awe dapat dilihat dari aspek ruang, waktu, dan tenaga. Aspek ruang dapat dilihat dari garis, volume, arah, dan fokus pandangan. Penggunaan garis, menggunakan garis lengkung sehingga memberikan kesan luwes. Penggunaan volume gerak yang sedang memberikan kesan feminin. Arah perpindahan gerak penari yang sederhana namun aktif memberikan kesan variatif. Fokus pandangan penari mengarah ke depan memberikan kesan percayadiri.

Nilai keindahan gerak awe-awe dilihat dari aspek waktu dapat dilihat dari aspek tempo, ritme, durasi dan irama. Penggunaan tempo yang sedang memberikan kesan manis (Apriani, 2018: 3). Durasi yang digunakan pada gerakan awe-awe tidak terlalu lama yaitu 2x8+4 hitungan, sehingga memberikan kesan yang tidak membosankan. Irama gerak yang digunakan memberikan daya hidup pada gerakan, sehingga memberikan kesan aktif dan menarik.

Nilai keindahan gerak awe-awe dilihat dari aspek tenaga dapat dilihat dari intensitas, aksen/tekanan, dan kualitas. Penggunaan intensitas tenaga yang sedang memberikan kesan seimbang dan terkontrol. Penggunaan aksen/tekanan yang besar memberikan kesan tegas. Kualitas gerak yang menampilkan antara gerak yang mengencang dan mengendor memberikan kesan energik dan lincah.

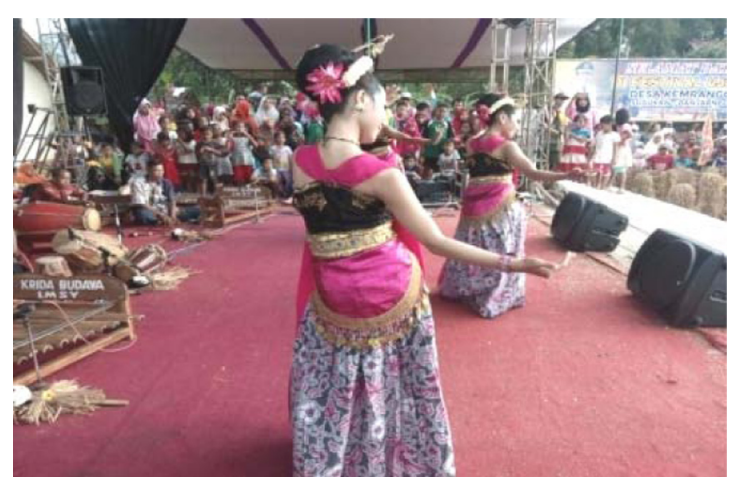

Gambar 4. Salah Satu Sikap dari Ragam

Gerak Awe-Awe

(Foto: Mutiara, 26 September 2018) 
Nilai keindahan gerak awe-awe dilakukan dengan meliuk namun bertekanan dan seksi. Gerak liukan badan yang dipadukan dengan gerakan kaki yang jinjit memberikan kesan lincah dan terlihat seksi. Penggunaan tekanan ketika kaki bergerak bergantian jinjit dengan tempo yang sedang memberikan kesan manis.

\section{KESIMPULAN}

Keindahan Tari Dadi Ronggeng dapat dilihat melalui tata hubungan antar unsur gerak yang dilakukan. Pola penggunaan ruang, waktu, dan tenaga menghasilkan nilai keindahan yang khas. Gerak pada Tari Dadi Ronggeng menghasilkan keindahan gerak yang lembut namun tetap bertenaga dan memiliki daya tarik danpesonayang tinggi padapenarinya, sehingga terlihat energik, seksi, dan ceria. Keindahan gerak yang terdapat pada Tari Dadi Ronggeng nampaknya akan sangat disayangkan jika tidak ada pembakuan gerak terhadap karya tersebut, dengan adanya keindahan gerak tersebut diharapkan ada pembakuan gerak sehingga Tari Dadi Ronggeng dapat dijadikan sebagai media pembelajaran dan sarana apresiasi bagi generasi milenial saat ini.

\section{DAFTAR PUSTAKA}

Apriani, Farida Nur., Sutiyono. 2018. Deskripsi Simbol Gerak Tari Jathil Obyog Massal 95an dalam Kesenian Reyog di Desa Pulung, Kabupaten Ponorogo. Imaji: Jurnal Seni dan Pendidikan Seni, Vol. 16, No. 1, 3.
Astini, Siluh Made dan Usrek Tani Utina. 2007. "Tari Pendhet Sebagai Tari Bali-Balihan (Kajian Koreografi)". Harmonia. Nomor 2. Hlm. 6. Semarang: Universitas Negeri Semarang.

Djelantik. 1999. Estetika Sebuah Pengantar. Bandung: Mayarakat Seni Pertujukan Indonesia.

Indriyanto. 2011. "Pengaruh Tari Jawa Pada Tari Baladewan Banyumasan". Harmonia. Hal. 57-67. Semarang: Universitas Negeri Semarang.

Noviyanti, Siti Risa., Sutiyono, S. 2017. Bentuk, Perubahan Fungsi, dan Nilai-nilai Edukatif pada Musik Tari Japin Tahlul di Amuntai. Imaji: Jurnal Seni dan Pendidikan Seni, 15(1), 97-112.

Jazuli, M. 1994. Telaah Teoretis Seni Tari. Semarang: IKIP Semarang Press.

Junaedi, Deni. 2017. Estetika: Jalinan Subjek, Objek dan Nilai. Yogyakarta: ArtCiv.

Sugiyono. 2013. Metode Penelitian Pendidikan (Pendekatan Kualitatif, Kuantitatif dam $R \& D)$. Bandung: Alfabeta.

Utina, Usrek Tani. 2009. "Pembelajaran Tari Berkonteks Tematik Berdasarkan Kurikulum Berbasis Kometensi di TK Pembina Singorojo Kabupaten Kendal". Harmonia. Hlm. 4. Semarang: Universitas Negeri Semarang. 